\section{Going with the flow}

This issue takes a look at how the products of crop biotechnology are affecting the environment. Since the late 1980s, many thousands of GM plants have been tested in field trials across the globe, with few apparent adverse environmental consequences. According to the notfor-profit International Service for the Acquisition of Agribiotech Applications, GM crops now cover more than 130 million acres worldwide - an area roughly equivalent to the size of Spain. So, if there has been no environmental cataclysm resulting from all these plantings, what are GM critics making so much fuss about?

Some crops tend to be sexually promiscuous, enjoying relations with any receptive relative that happens to be nearby. The flow of genes between a crop and its close wild relations occurs via pollen and/or indirectly via the resultant offspring, which further spread genes by the dispersal of pollen and seeds

The potential for pollen-based gene flow depends on the geographical spread of the crop and of its wild relatives. With plants such as sunflower, squash, and radish, wild relations and the cultivated plant are different forms of the same species and grow in similar locations; thus, there is a high potential for mating. In contrast, in the US at least, maize, cotton, soybean, and potato have no wild or weedy relatives in the neighborhood, making gene spread more unlikely. There are nevertheless at least 44 cultivated plant species that have the potential to mate with one or more wild relatives somewhere in the world. With plenty of data suggesting that DNA flies around all over the place down on the farm, evaluations of the risks associated with new cultivars usually assume that gene flow from crops to relatives can occur.

When the chance that genes will flow around the environment is designated as $100 \%$, the assessment of the environmental risks for a new cultivar becomes an assessment of the consequences of that gene flow. It is not gene flow per se that is going to represent the environmental hazard. Gene flow-the "genetic contamination" vaunted by those opposed to GM crops-is as normal and natural, well, as agriculture itself. It is what the genes do after they arrive that is relevant to risk assessment. It is anticipating or quantifying the hazards (if any) associated with a particular plant's accruing a particular trait in a particular environment that presents the real challenge.

The rapid spread of genes that confer to related weeds or crops novel fitness-related traits that were not previously available is a particular concern for GM varieties. For example, a report from the UK government's advisors on the environment, English Nature, in February cited evidence that in Canada, canola plants resistant to three herbicides (Roundup, Liberty, and Pursuit) have emerged in just two years as a result of cross-pollination. (Tolerance to Pursuit, by the way, was not conferred by recombinant DNA technology, which reinforces the view that environment impact assessment is not a GM-specific issue.) The most pressing issue in environmental assessment, however, is not whether such resistance strains can emerge, but what the consequences of their emerging will be.

Irrespective of the above concerns, companies offering GM varieties need to consider the liabilities and financial risks attendant on their reluctance to improve on present containment strategies (see p. 537). Europe, the second-largest trading block in the world, has made a deci- sion (albeit scientifically unjustifiable) to discriminate against GM products on the basis of process rather than products. Because gene containment is next to impossible with the current generation of GM crops, this discriminatory stance has led to several international "incidents" over the past few years. These have included the burning of hundreds of acres of two Pioneer Hi-Bred non-GM corn varieties "contaminated" with foreign genes in Switzerland (Nat. Biotechnol. 17, $629,1999)$ and the ploughing down in 2000 of 600 hectares of canola in France that also contained traces of GM material. In either case, companies were forced to compensate farmers many hundreds of thousands of dollars.

The accidental pollination of crops intentionally grown for organic produce has already occurred in Canada, where the presence of GM material in canola disqualified growers from organic certification. At the beginning of the year, the Saskatchewan Organic Directorate initiated a class action suit against Monsanto and Aventis CropScience to seek compensatory damages for revenues lost (Nat. Biotechnol. 20, $210,2002)$. One interesting side note to this is that organic certification is a form of self-regulation imposed, in essence, by organic farmers on organic farmers. The rules have been established so that all organic farmers play on a level field. "No GM" is one of these rules. Having established themselves as rule-makers, law enforcement agencies, and juries, organic certification bodies are now endeavoring to obtain judgments from legislative bodies that had no part in establishing the rules in the first place.

Gene flow from GM crops to related plants thus remains a primary concern for regulators, and one that companies need to address. Current gene-containment strategies cannot work reliably in the field. Seed companies will continue to confuse batches, and mills will continue to mix varieties. Although "buffer zones" may theoretically control pollen dispersal (and gene spread), in practice farmers will be unable (or unwilling) to follow planting rules. Can we reasonably expect farmers to their agricultural equipment meticulously enough to remove all GM seed?

Most seriously, gene flow (like mixing) could result in GM material unintended for human consumption ending up in the human food chain. When corn products were found that contained Aventis' Starlink corn (which was approved only for use in animal feed), the resulting scramble to recall tacos and corn products cost a staggering $\$ 1$ billion overall. Again, actually exploring the consequences of this "adventitious presence" was a secondary issue. The troubling fact was that a GM crop not approved in the US for human consumption found its way onto dining tables. The adventitious presence of Starlink in tacos had no consequences for human health, but could the same be said of a crop variety designed for biopharmaceutical production?

It is essential that new molecular gene-containment strategies, such as those outlined on p. 581, be developed and introduced. Technologies now available for excision of selectable markers (p. 575) should also be considered. It is time that industry took decisive steps to address gene flow from their products. Environmental concerns surrounding GM crops are not going to go away. 